\title{
Effect of etoposide on grass pea DNA topoisomerase II: an in silico, in vivo, and in vitro assessments
}

\author{
Aveek Samanta ${ }^{1}$, Tilak Raj Maity², Sudip Das², Animesh Kumar Datta ${ }^{3}$ and Siraj Datta ${ }^{2^{*}}$ (D)
}

\begin{abstract}
Background: Etoposide is one of the most potential anti-cancerous drugs that targets topoisomerase II (topoll) and inhibits its activity by ligation with the DNA molecule.

Results: In silico study confirmed that the etoposide-binding sites of topoll are conserved among the plants and human. The efficacy of the drug on plant system was initially assessed using germinated grass pea (Lathyrus sativus L.) seedlings (in vivo) in relation to radicle length and mitotic index. The callus system (in vitro) was also used to elucidate the effect of etoposide on callus growth kinetics. Furthermore, it was observed that etoposide able to inhibit the division of polyploid cells induced by colchicine treatment $(0.5 \%, 8 \mathrm{~h})$. To determine the molecular interaction, topoll was isolated from young grass pea leaves using polyethylene glycol fractionation and ammonium sulphate precipitation followed by column chromatography on CM-Sephadex (C-25). The plasmid linearization assays by isolated plant topoll in the presence of etoposide significantly revealed the functional similarity of plants and human topoll. Results indicated that the effect of etoposide on plant topoll is significant.
\end{abstract}

Conclusions: This study may pave the way to develop a plant-based assay system for screening the topoisomerase targeted anti-cancerous drugs, as it is convenient and cost-effective.

Keywords: Callus growth kinetics, Etoposide, Lathyrus sativus L., Mitotic index, Topoisomerase II, Topoisomerase assay

\section{Background}

New drug discovery for cancer treatment is facing serious challenges due to limited number of approvals because of complex screening processes (Batra and Sharma 2013; Denayer et al. 2014), high cost, and stringency in the use of animal model/cell culture (Astashkina et al. 2012). It widens the necessity to explore a simple and cost-effective novel approach for drug discovery based on plant system. Plants and animals originated from a common ancestor (Meyerowitz et al. 2002) though they are structurally and functionally different but their basic cellular activities namely, cell cycle, DNA replication, and its regulations are conserved in nature (Elledge 1996; Shirahige 1998; Jensen 2006; Sclafani and Holzen 2007). Like in animal system, it may be assumed that in

\footnotetext{
*Correspondence: dattasiraj@gmail.com

${ }^{2}$ Department of Biotechnology, Haldia Institute of Technology, Purba

Medinipur -, Haldia, West Bengal 721657, India

Full list of author information is available at the end of the article
}

plant system as well, cell cycle regulatory proteins or check points can be the potential target for anti-cancer compound(s) to block the different steps of cell cycle and cell division.

Etoposide is an important and widely used anti-cancerous drug mostly effective against lung cancer, lymphoma, and leukemia (Issell 1984; Hande 1998; Baldwin and Osheroff 2005). The functional activity of etoposide is to inhibit the topoisomerase II (topoII), which is an essential enzyme for DNA replication. TopoII is responsible for relaxing, unknotting, and untangling the DNA by generating the transient double strand breaks in a separate segment of DNA (Wang 1995; Nitiss 1998; Champoux 2001; Wang 2002). Etoposide, topoII, and DNA form a drug-enzyme-DNA ternary complex, which is a critical stoichiometry for the drug activity (Nitiss 1994; Fortune and Osheroff 2000). Etoposide stabilizes the cleavage complex created by topoII with DNA and thereby inhibits the functional activity of the enzyme. Etoposide contains five rings namely A, B, C, D, and E 
(McClendon and Osheroff 2007). The E ring is mainly responsible for interaction with G-478, D-479, L-502, and R-503 amino acids of human topoI (Wu 2011) which is an isoform of topoII. The drug prevents cell cycle progression in late $S$ and $G_{2}$ phase, and when exists in sufficient concentration trigger apoptosis (Loike and Horwttz 1976; Felix 1998; Kaufmann 1998; Kaufmann et al. 1998; Rowley 1998; Wilstermann and Osheroff 2003).

Isolation and characterization of topoII in higher plants are rather meager maize embryos (Carballo et al. 1991), cauliflower (Fukata and Fukasawa 1982, 1983), pea leaves (Rudenko 1992), and Arabidopsis inflorescence (Xie and Lam 1994). Furthermore, from available literature, it seems that there is no report about the effect of etoposide on plant topoII. The present article describes the effect of etoposide on plant system using Lathyrus sativus L., Family: Fabaceae in vivo and in vitro. In silico study from available gene database is performed to assess the structural and functional similarities between human and plant topoII. The objective of the work is to foresee the effectivity of etoposide on plant system which can open up the possibility of using plant system for screening of topoisomerasetargeted anti-cancerous drugs. The plant system as a model is convenient to use and is cost-effective.

\section{Materials and methods}

\section{Plant material}

Grass pea (Lathyrus sativus L., Family: Fabaceae) seeds obtained from plants grown in the experimental garden of the Haldia Institute of Technology $\left(22.03^{\circ} \mathrm{N}\right.$ and $88.06^{\circ} \mathrm{E}$ ) during mid-April.

\section{Treatments}

Seeds collected from mature plants were air-dried surface sterilized $\left(0.1 \% \mathrm{HgCl}_{2}\right)$ for $5 \mathrm{~min}$, washed by distilled water (3 times, $10 \mathrm{~min}$ each), and finally soaked in triple distilled water $(12 \mathrm{~h})$. The seeds were then kept on Petri plates lined with cotton-soaked etoposide (GLS Pharma Ltd., India; MW 588.557) solution (25, 50, 75, $100,125$, and $150 \mu \mathrm{M})$ for $72 \mathrm{~h}$ and for time-dependent assay solution with drug $(50,100$, and $150 \mu \mathrm{M})$ treated for 24,48 , and $72 \mathrm{~h}$ and then on distilled water $(25 \pm$ $2{ }^{\circ} \mathrm{C}$ ). Colchicine (aqueous solution $-0.5 \%, 8 \mathrm{~h}$; prior treatment)-treated seeds were also kept in different concentrations of etoposide for $72 \mathrm{~h}$.

The seeds soaked in distilled water $(12 \mathrm{~h})$ have been marked as control A while colchicine $(0.5 \%, 8 \mathrm{~h})$-treated seeds considered as control B.

\section{In silico study}

Amino acid sequence of human and plant topoII $\beta$ was retrieved from NCBI database (http://www.ncbi.nlm.nih. gov/). The sequences that share $95 \%$ or higher identity were considered as likely alleles (Zang et al. 2001; Wang et al. 2004) and aligned in CLUSTALW multiple sequence alignment tool (Thompson et al. 1997). From this alignment, the cleavage core of drug interacting residues (40 aa) was analyzed using WebLogo (http://weblogo.berkely. edu/logo.cgi) software for visualizing the similarities of drug interacting amino acid residues among plant species and human beings.

\section{Assessment of radicle length and determination of mitotic index (MI)}

Radicle length ( $\mathrm{mm}$ ) was measured from germinating seedlings (randomly 25 seedlings from each set) on the 3rd day of treatment $(72 \mathrm{~h})$. Seedling morphology was also studied. Experiment was performed with 3 replicas including control A and control B.

Mitotic study was performed from root tips $(2 \mathrm{~mm})$ collected from the control and treated material, fixed in acetic alcohol (1:3) for $3 \mathrm{~h}$, preserved in $70 \%$ alcohol, and kept under refrigeration. The tips were stained in $2 \%$ orcein- $\mathrm{HCl}$ $(1 \mathrm{~N})$ mixture and squashed in $45 \%$ acetic acid. Mitotic index (MI) was determined using the formula: $\mathrm{MI}=$ (dividing cells/total number of cells) $\times 100$. Frequency of polyploid cells was estimated from dividing cells.

\section{Callus growth kinetics in response to etoposide treatments}

Grass pea callus line was initiated in accordance with protocol reported earlier (Samanta et al. 2014). Callus growth was initiated using hypocotyls as explant on MS media (Murashige and Skoog 1962) supplemented with $16.11 \mu \mathrm{M}$ NAA ( $\alpha$-naphthalene acetic acid) and $2.32 \mu \mathrm{M}$ KIN (Kinetin). Different concentrations of etoposide (25, $50,75,100,125$, and $150 \mu \mathrm{M})$ solution were sterilized (using $0.2 \mu \mathrm{m}$ membrane filter) and added to the different sets of medium. For each experiment (10 sets), $0.1 \mathrm{~g}$ of callus was transferred to fresh medium (control and treatments). The fresh weight of the callus was measured, and the morphology of the calli was also observed at an interval of 5 days up to 35 days to calculate its growth kinetics followed by the equation of Hunt and Loomis 1976.

\section{Isolation of DNA topoll from young grass pea leaf}

Freshly collected grass pea leaves $(100 \mathrm{~g})$ were homogenized with $250 \mathrm{ml}$ TEM buffer $(50 \mathrm{mM}$ Tris- $\mathrm{HCl}$ at $\mathrm{pH}$ 8, $1 \mathrm{mM}$ EDTA, and $5 \mathrm{mM} \beta$-mercaptoethanol) and centrifuged at $12,000 \mathrm{~g}$ for $45 \mathrm{~min}$ at $10^{\circ} \mathrm{C}$. PEG-6000 (10\%) and $2 \mathrm{M} \mathrm{NaCl}$ were added in the supernatant to remove the nucleic acids. Supernatant was collected and precipitation was done by solid ammonium sulphate (55\% saturation). Following centrifugation at $12,000 \mathrm{~g}$ for 30 min at $10^{\circ} \mathrm{C}$, a protein cake was accumulated at the middle phase between PEG and ammonium sulphate. The protein cake was collected and dissolved in $250 \mathrm{ml}$ TGD buffer $(50 \mathrm{ml}$ Tris- $\mathrm{HCl}$ at $\mathrm{pH} 8,20 \%$ glycerol, 0.05 
$\mathrm{mM}$ dithiothreitol) and again centrifuged to get the clear supernatant. The supernatant was loaded on CM-Sephadex column (C-25) pre-equilibrated with TGD buffer. The column was extensively washed with the TGD buffer. The bound topoII enzyme was eluted with $\mathrm{KCl}$ with five-step gradients (100 mM, $120 \mathrm{mM}, 140 \mathrm{mM}, 160 \mathrm{mM}$, and 180 $\mathrm{mM}$ ) in TGD buffer. The elution was collected by fraction collector and protein-containing fractions were stored by measuring their optical density (OD) at $280 \mathrm{~nm}$.

\section{Sodium dodecyl sulfate polyacrylamide gel electrophoresis (SDS-PAGE)}

SDS-PAGE was performed according to Laemmli (1970) to identify the topoII in different samples using a mini gel apparatus (Bio-Rad): crude (before ion-exchange) and different fraction from CM-Sephadex column (C-25). Samples $(0.1 \mu \mathrm{g}$ of protein) were diluted in SDS-containing sample buffer with $\beta$-mercaptoethanol (under reducing condition) prior to loading. Electrophoresis was performed at room temperature at $16 \mathrm{~mA}$ during stacking and $18 \mathrm{~mA}$ per plate during resolving. Protein-containing bands were visualized by silver staining method (Oakley et al. 1980). The protein bands were analyzed by comparing with standard MW marker.

\section{Time-dependent plasmid linearization assay by isolated plant topoll to confirm its activity}

The DNA topoisomerase activity assay was performed on relaxation of negatively supercoiled duplex plasmid
DNA (pBluecript SK+; pBS) as was described earlier by Nitiss et al. (2012) and visualized by agarose gel electrophoresis. The standard reaction mixture $(25 \mu \mathrm{l})$ composed of $50 \mathrm{mM}$ Tris- $\mathrm{HCl}(\mathrm{pH} 7.5), 10 \mathrm{mM} \mathrm{MgCl} 2,0.5$ $\mathrm{mM}$ ATP, $1 \mathrm{mM}$ dithiothreitol, $160 \mu \mathrm{g} / \mathrm{ml}$ bovine serum albumin (BSA), $0.5 \mu \mathrm{l}$ plasmid DNA, and $5 \mu \mathrm{l}$ enzyme solution. The reaction mixtures were incubated at $35^{\circ} \mathrm{C}$ and reactions were stopped after different time interval $(0,10,20,30$, and $60 \mathrm{~min})$ by adding either of $3 \mu \mathrm{l}$ of $5 \%$ sodium dodecyl sulphate (SDS) or $3 \mu$ l of etoposide $(5 \mu \mathrm{M})$. A second reaction mixture comprising of $10 \mathrm{X}$ EcoR1 buffer, $0.5 \mathrm{~mm}^{3}$ plasmid DNA and $2 \mu \mathrm{l}$ EcoR1 to prepare fully relaxed DNA. Agarose gel electrophoresis, ethidium bromide staining, and gel documentation were done as described previously (Datta et al. 2008).

\section{Plasmid linearization assay by isolated plant topoll at different concentration of etoposide}

The plasmid linearization assay in the presence of increased etoposide concentration was performed using the same reaction mixture $(25 \mu \mathrm{l})$ as described previously, $0.5 \mu \mathrm{l}$ plasmid DNA, and $5 \mu \mathrm{l}$ enzyme solution with etoposide $(10,20,30$, and $40 \mu \mathrm{M})$. The final reaction mixtures were incubated at $35^{\circ} \mathrm{C}$ for $60 \mathrm{~min}$. A second reaction mixture of $10 \mathrm{X}$ EcoR1 buffer, $0.5 \mu \mathrm{l}$ plasmid DNA, and $2 \mu \mathrm{l}$ EcoR1 was also incubated for 60 min at $35^{\circ} \mathrm{C}$ to prepare fully relaxed DNA.

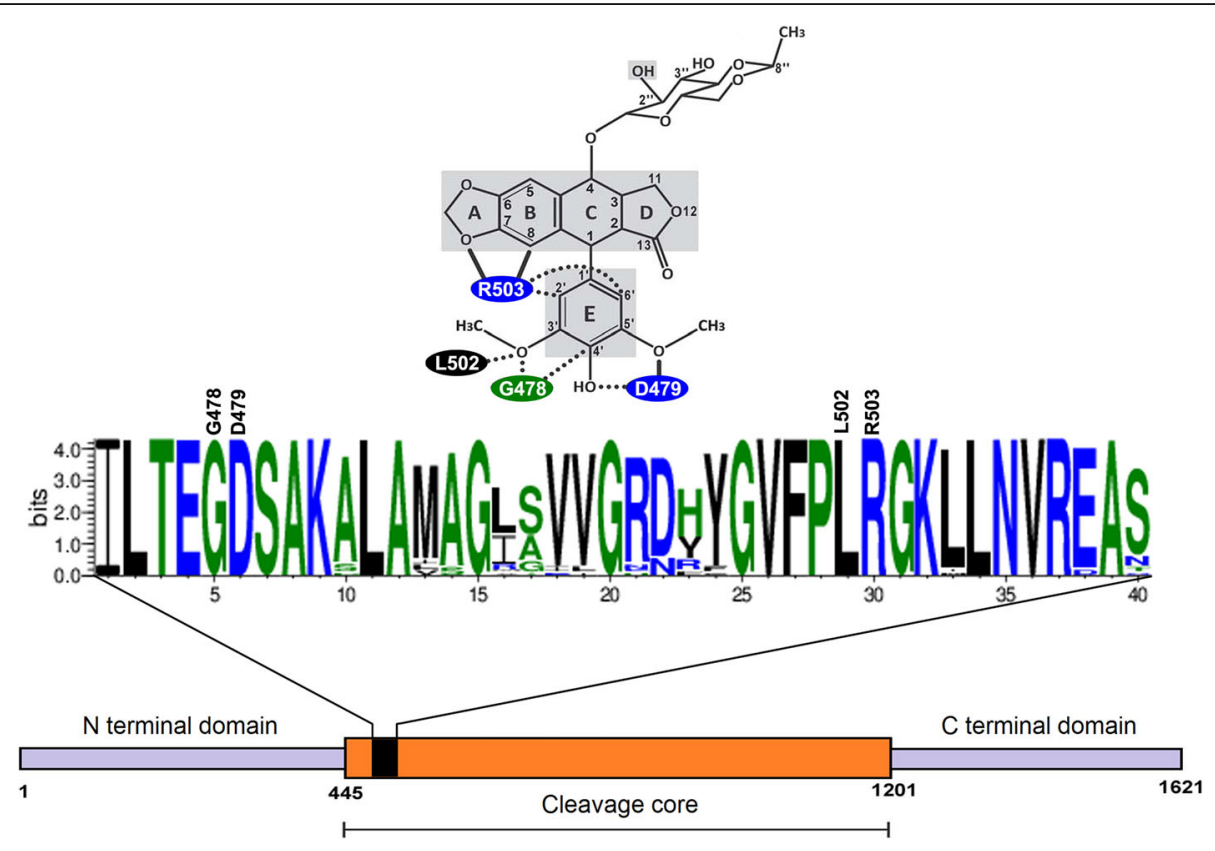

Fig. 1 The etoposide-binding region inside the cleavage core of topoisomerase II is shown with WebLogo result. Conserve amino acid sequences of 38 different plant species and human are represented in this cleavage core. The data for this logo consists of 40 amino acids. The chemical structure of the drug and its interacting sites (G-478, D-479, L-502, R-503) (above) and topoll domain structure (below) are shown in the figure 


\section{Results}

Structural similarities of DNA-binding cleavage core domain of plants topoll and human topoll $\beta$

The length of human topoII $\beta$ polypeptide is about 1621 amino acids long (Wu et al. 2011), and it contains Nterminal domain, cleavage core, and C-terminal domain (Mirski and Cole 1995; Adachi et al. 1997; McClendon and Osheroff 2007). The phylogenetic tree (Additional file 1: Figure S1) and multiple alignment of the amino acid sequence among plant and human (Additional file 2: Figure S2) indicate that the cleavage core domain of topoII is conserved. The WebLogo represents that the cleavage core domain of topoII and the specific etoposide interacting residues with topoII G-478, D-479, L-502, and R-503 are well conserved among plants and humans (Fig. 1).

\section{Assessment of radicle length and mitotic index}

Radicle length (control A, $19.7 \mathrm{~mm} \pm 1.2$; treatments, $11.8 \mathrm{~mm} \pm 1.1$ to $3.9 \mathrm{~mm} \pm 0.7$ ) and mitotic index (control A, $12.11 \%$; treatments, 5.48 to $0.05 \%$ ) are found to decrease with an increase concentration of etoposide (Fig. 2a and Fig. 3a). Radicle length and mitotic index also decrease with time $(24,48$, and $72 \mathrm{~h})$ when treated with etoposide (Table 1). All the attributes significantly correlate $(p \leq 0.05)$ between themselves suggesting that etoposide possesses the potential effect on cell division.

\section{Effect of colchicine and its reversal}

Colchicine treatments (control B) induce bulging of radicle tips (Fig. 3b) of grass pea seedlings. The frequency of dividing polyploid cells is found to be $5.60 \%$ along with an enhancement in cell size and nuclear volume. Bulging of radicle tips shows diminishing tendency with the increase concentration of etoposide, and it is observed phenotypically normal from $75 \mu \mathrm{M}$ concentration onwards. Frequency of polyploid cells is found to reduce from $2.98 \%(25 \mu \mathrm{M})$ to $0.66 \%(75 \mu \mathrm{M})$ and finally to $0.0 \%$ from $100 \mu \mathrm{M}$ etoposide concentration onwards (Fig. 2b) indicating that etoposide could inhibit polyploid cell formation in grass pea. In relation to control $\mathrm{B}$, mitotic index (control, 8.90\%; treatments, 3.25 to $0.00 \%$ ) and radicle length (control, $8.01 \mathrm{~mm} \pm 1.57$; treatments, $6.59 \mathrm{~mm} \pm 1.11$ to $4.16 \mathrm{~mm} \pm 0.89)$ also reduce with the increased concentration of etoposide.
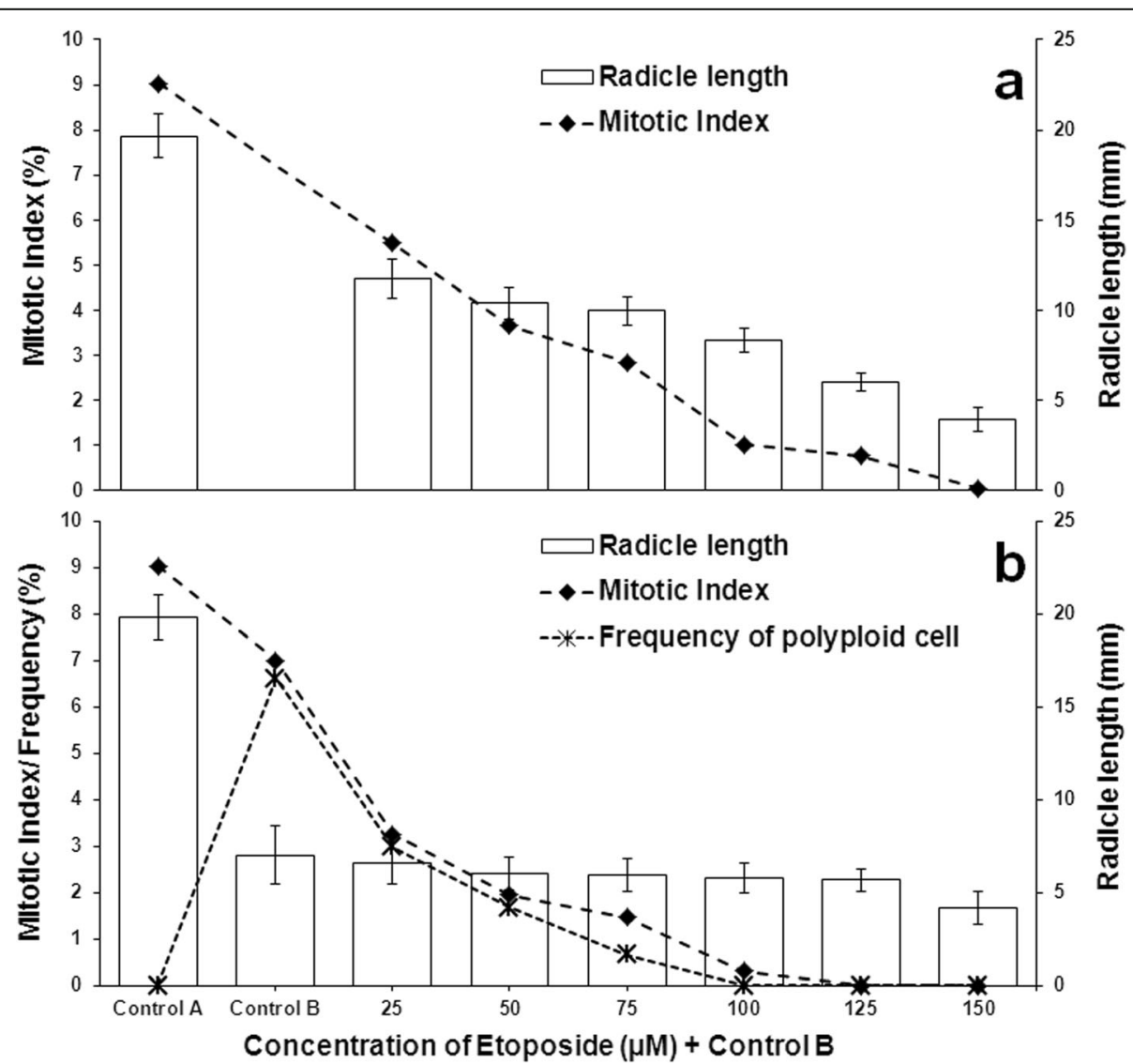

Fig. 2 Effect of different concentrations of etoposide in grass pea seedlings for $72 \mathrm{~h}$. a Radicle length and mitotic index in the presence of etoposide ( $72 \mathrm{~h}$ ). b Assessment of radicle length, mitotic index, and frequency of polyploid cells with the treatment of colchicine ( $8 \mathrm{~h}$ ) followed by different concentrations of etoposide $(72 \mathrm{~h})$ 


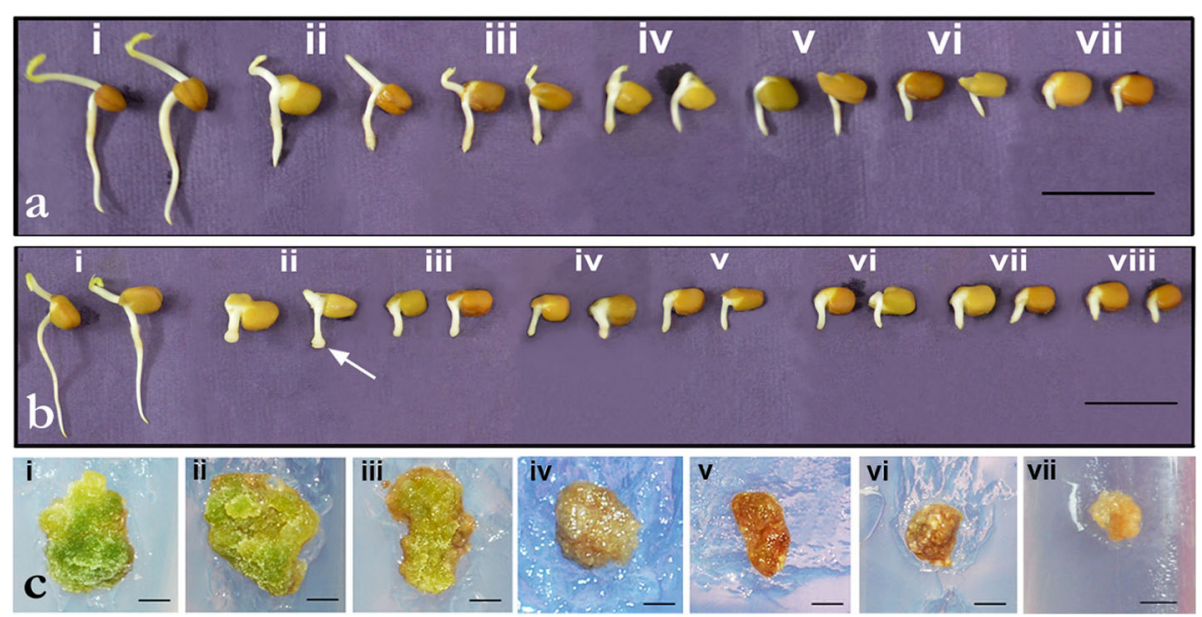

Fig. 3 Effect of different concentrations of etoposide in grass pea for $72 \mathrm{~h}$. a Treatments showing reduced radicle length with increasing concentration of the etoposide (i to vii: $0,25,50,75,100,125$, and $\mu \mathrm{M}$ ) treated for $72 \mathrm{~h}$. $\mathbf{b}$ Assessment of radicle length, with the treatment of colchicine ( $8 \mathrm{~h}$ ) followed by different concentrations of etoposide for $72 \mathrm{~h}$. i, control A; ii, control B showing distinct bulging of root tips; iii to viii, significant decrease in bulging tendency of root tips with lower to higher concentrations of drugs added. c Callus growth inhibition with increased concentration of etoposide (i to vii: 0 , $25,50,75,100,125$, and $150 \mu \mathrm{M})$. The callus picture representing the 30th day's morphology. i, control; ii to vii, showing a decrease in callus size with lower to higher concentrations of etoposide added in the medium. Scale bar $=10 \mathrm{~mm}$ (Fig. 3a,b); $5 \mathrm{~mm}$ (Fig. 3c)

\section{Effect of etoposide on callus growth kinetics}

Etoposide shows dose-dependent inhibition in callus growth (Fig. 4a). The effect of etoposide on callus growth rate has been presented in Fig. 4b, a good estimation of maximum specific growth rate of callus. Browning and necrosis of callus tissues are also observed from $75 \mu \mathrm{M}$ concentration onwards (Fig. 3c).

\section{Isolation and purification profile of DNA topoll}

Sodium dodecyl sulfate polyacrylamide gel electrophoresis (SDS-PAGE) has been performed for identification of the topoII in different samples. SDS gel electrophoresis of the active fractions of isolated topoII after ion-exchange chromatography on CM-Sephadex column (C-25) shows protein bands near $100 \mathrm{kDa}$ (Fig. 5; lanes 1, 2, and 3).

\section{Time-dependent plasmid linearization assay by isolated} grass pea topoll to confirm its activity

DNA relaxing activity of enzyme converts supercoiled pBS

DNA into nicked and linear forms (Fig. 6a, b) exhibiting relatively low electrophoretic mobility. When the reactions were stopped at different time intervals $\left(T_{0}-T_{60}\right)$ by adding the SDS or etoposide, there has been a decrease in amount of supercoiled plasmid with concomitant increase of nicked and linear DNA (Fig. 6a, b).

Degradation of supercoiled plasmid DNA in the presence of topoll with increased concentration of etoposide

The purified plant topoII converts supercoiled pBS DNA into nicked and linear forms. Treatment of supercoiled plasmid by the topoII shows supercoiled, nicked, and some linear DNA (Fig. 7). When the same experiment is done in the presence of increased concentrations of etoposide (10 to $40 \mu \mathrm{M}$ ), initially there has been a decrease in the amount of nicked DNA with an increase in amount of linear DNA. On the other hand, increasing concentration of etoposide $(\geq 20 \mu \mathrm{M})$ has been a concomitant decrease in band intensity and smearing of DNA, which signifies the cleaving of DNA at multiple sites. It seems that like human topoII, etoposide acts in a similar fashion on plant topoII as well.

Table 1 Time-dependent effect of etoposide on radicle length and mitotic cell division

\begin{tabular}{|c|c|c|c|c|c|c|}
\hline \multicolumn{7}{|c|}{ Treatment of drug (etoposide) for time dependent manner } \\
\hline \multirow{2}{*}{$\begin{array}{l}\text { Etoposide } \\
\text { concentration } \\
(\mu \mathrm{M})\end{array}$} & \multicolumn{2}{|c|}{$24 \mathrm{~h}$} & \multicolumn{2}{|l|}{$48 \mathrm{~h}$} & \multicolumn{2}{|l|}{$72 \mathrm{~h}$} \\
\hline & Radicle length (mm) & Mitotic index \% & Radicle length (mm) & Mitotic index \% & Radicle length (mm) & Mitotic index \% \\
\hline Control & $19.70 \pm 1.2$ & 9.02 & $19.70 \pm 1.2$ & 9.02 & $19.7 \pm 1.2$ & 9.02 \\
\hline 50 & $16.21 \pm 1.3$ & 5.40 & $12.44 \pm 1.6$ & 4.90 & $10.4 \pm 0.9$ & 3.66 \\
\hline 100 & $12.84 \pm 1.2$ & 5.00 & $10.60 \pm 0.8$ & 3.00 & $8.3 \pm 0.7$ & 1.01 \\
\hline 150 & $10.36 \pm 0.9$ & 3.40 & $6.32 \pm 0.9$ & 1.30 & $3.9 \pm 0.7$ & 0.05 \\
\hline $\operatorname{LSD}(P \leq 0.05)$ & 1.22 & 0.67 & 0.52 & 0.39 & 0.75 & 0.35 \\
\hline
\end{tabular}



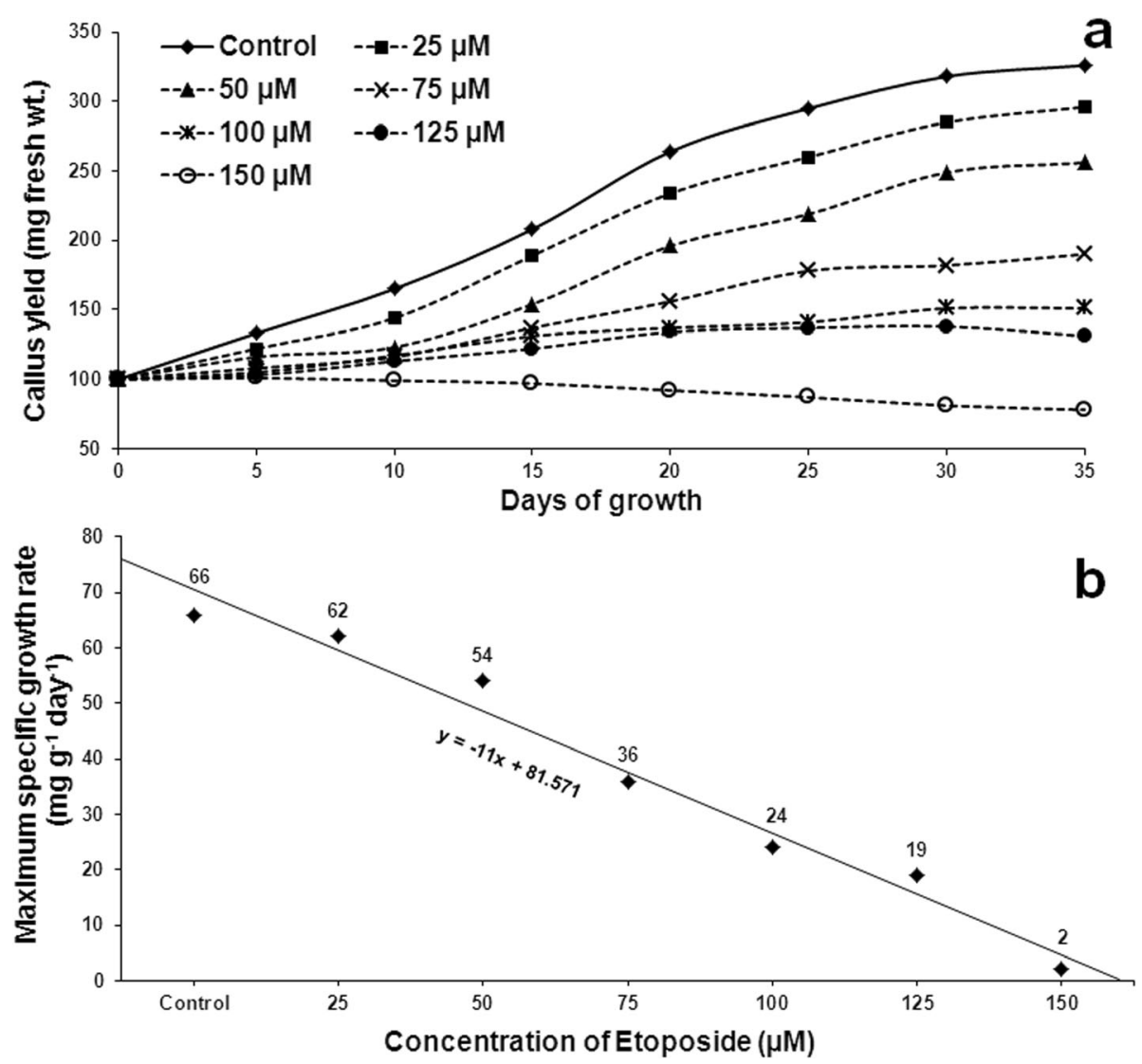

Fig. 4 Effect of increasing concentrations of etoposide on callus growth kinetics. a Callus growth inhibition rate with time (in days) when the media contain increased concentration of etoposide. $\mathbf{b}$ The maximum-specific growth rate of callus with increased concentration of etoposide during in vitro culture

\section{Discussion}

The structural relationship between plants and human topoll $\beta$

The present investigation reveals that the basic structure of etoposide-binding domain is similar in both plants and

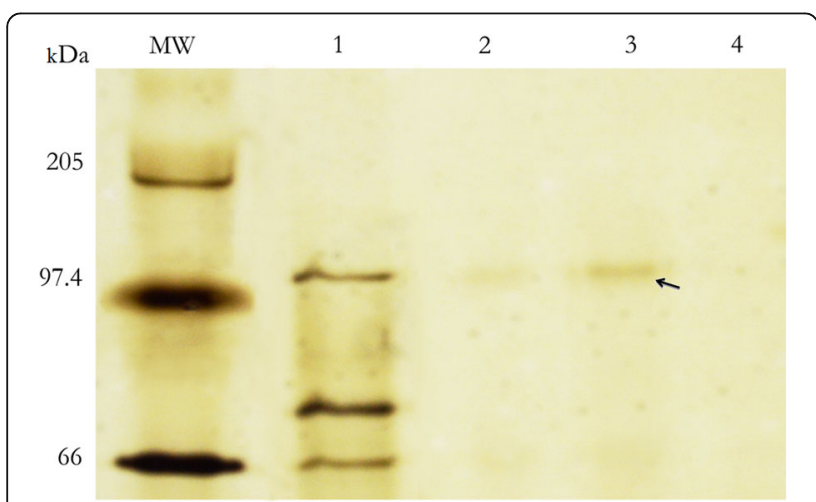

Fig. 5 Purification profile of topoll isolated from L. sativus by $7.5 \%$ SDS-PAGE. MW: molecular weight standard in $\mathrm{kDa}$; lane 1,55\% ammonium sulfate precipitate suspension; lanes 2 to 4 , fraction of CM-cephadex chromatography eluted by $100 \mathrm{mM}, 120 \mathrm{mM}$, and 160 $\mathrm{mM}$ of $\mathrm{KCl}$ respectively in TGD buffer of $\mathrm{pH} 8$ humans. Therefore, it is expected that etoposide can bind with plant topoII and inhibits its function. The etoposidebinding domain is present inside the cleavage core. The specific etoposide interacting residues (G-478, D-479, L502, and R-503) of topoII are conserved between plants and human (Wu et al. 2011). The overall structural conformation of topolls are similar in bacteria and yeast as well (Dong and Berger 2007; Bax et al. 2010; Laponogov et al. 2010). Etoposide inhibits the topoII activity by stabilizing cleavage complex created by enzyme during DNA replication (McClendon and Osheroff 2007). Plant cell also possesses topoII with similar function as that of animals (Fukata and Fukasawa 1982; Xie and Lam 1994).

The drug etoposide contains five rings namely A, B, C, $D$, and $E$ (McClendon and Osheroff 2007). The E ring interacts with glycine (G) 478, aspartate (D) 479, and leucine (L) 502 of topoII $\beta$ protein. A Van der Waals interaction is also observed with the glycosidic group of etoposide and glutamine (Q) 778 and methionine (M) 782 of topoI (Wu et al. 2011). Wu et al. (2011) also determined the high-resolution crystal structure of the DNA-binding and cleavage core domain of the human topoII $\beta$ isoform (residues 445 to 1201; here-in-after 


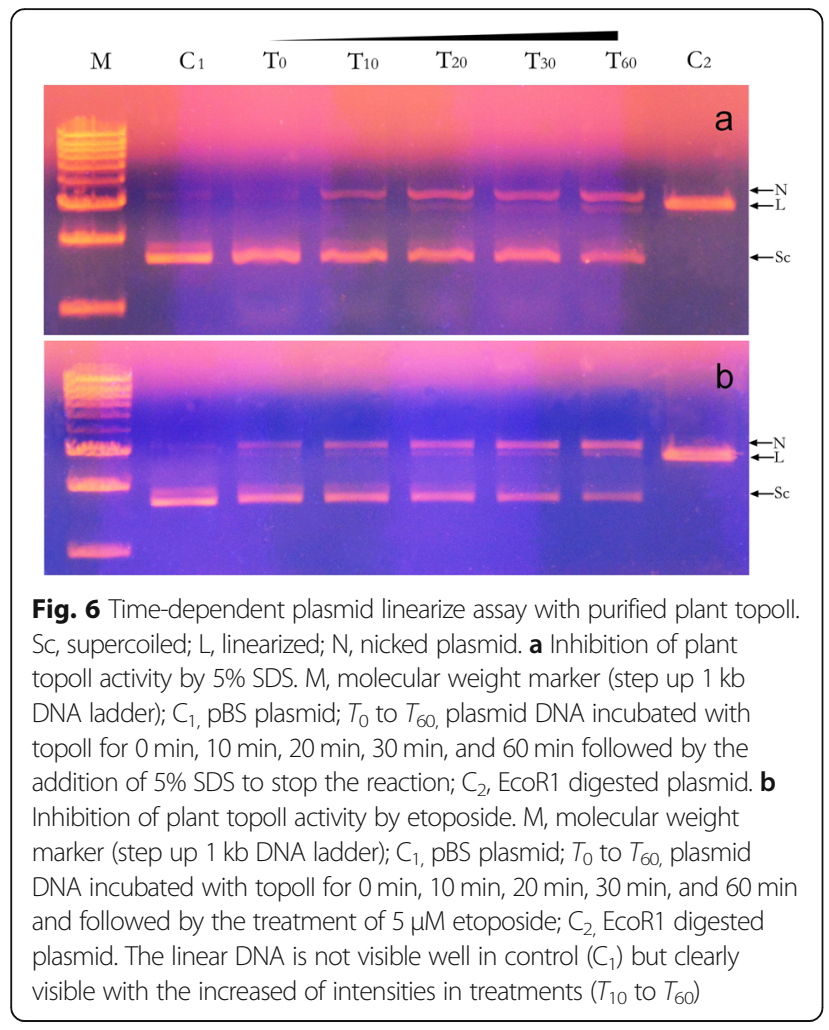

abbreviated human topoII $\beta$ core) in complex with DNA and the anti-cancer drug etoposide. The overall structure of the human topoII $\beta$ core dimer adopts a more open quaternary conformation than in other DNAbound structures as previously reported for bacterial and yeast topolIs (Dong and Berger 2007; Bax et al. 2010; Laponogov et al. 2010) with significant changes in the relative orientations between the main DNA-contacting domains of the two etoposide monomers. The topoII activity has been partially purified and biochemically

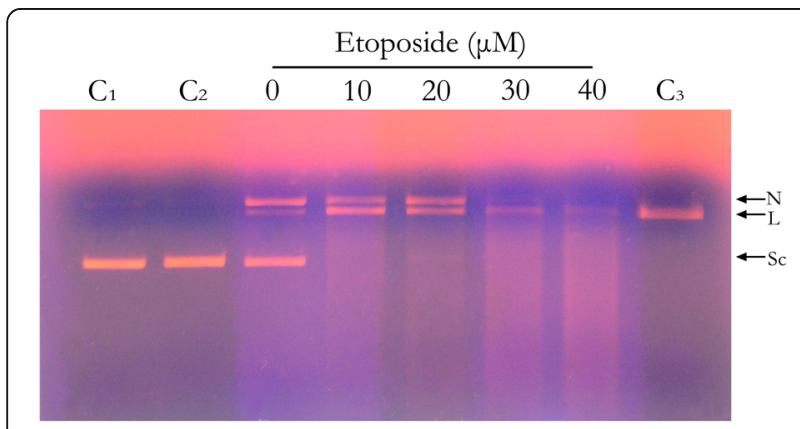

Fig. 7 Plasmid linearize assay by purified plant topoll with increasing concentration of etoposide. $C_{1}$, pBS plasmid; $C_{2}$, plasmid and etoposide; Lanes 3 to 7, plasmid DNA incubated with purified plant topoll and etoposide $(0,10,20,30$, and $40 \mu \mathrm{M}) ; C_{3}$, EcoR1 digested plasmid. With the increasing concentrations of etoposide $(\geq 20 \mu \mathrm{M})$ smearing of DNA are appeared due to the cleavage of DNA at multiple sites characterized from cauliflower inflorescence (Fukata et al. 1986) and pea (Pisum sativum) leaves (Rudenko 1992). Their biochemical properties of topoII are similar to those of the other eukaryotic topolIs. The enzyme topoII has also been found in higher plant chloroplasts (Lam and Chua 1987) and also evident by immunological analyses (Pyke et al. 1989). The chloroplast enzyme may be similar to bacterial gyrase, since both can relax supercoiled DNA substrates in the presence of ATP (Lam and Chua 1987) and has an apparent molecular weight of about $100 \mathrm{kDa}$ (estimated by Western blot with a heterologous antitopoII antiserum) (Pyke et al. 1989). Thus, it apparently appears that etoposide which is a potent inhibitor of human topoII also binds with plant topoII and possibly inhibits the enzyme action in a similar way.

\section{The functional relationship between plants and human topoll $\beta$}

Time-dependent activity study of isolated plant topoII using supercoiled pBS shows that concentration of relaxed and nicked DNA increases with concomitant decrease of supercoiled DNA (Fig. 6a, b) with respect to the time of incubation. Results of plasmid linearization assay support that etoposide can also inhibits the functional activity of plant topoII, thereby suggesting that etoposide acts in the similar way in plant and human topoII. In the present study, grass pea topoII shows a protein band near $100 \mathrm{kDa}$ as identical to that reported (Pyke et al. 1989) in Arabidopsis thaliana.

The plasmid linearization assay with increasing concentration of etoposide indicates that pBS is present in supercoiled form in the first two lanes where no topoII is present (Fig. 7). In 3rd lane, topoII causes nicking of plasmid and create relaxed and nicked form of plasmid. With the increasing concentrations of etoposide $(\geq$ $20 \mu \mathrm{M}$ ), smearing of DNA appears suggesting cleavage of DNA at multiple sites in lanes (4th to 7th). Higher concentrations of etoposide prevent the relegation activity of topoII (Pommier et al. 2010).

\section{In vivo and in vitro studies}

The reduction of radicle length, mitotic index, and inhibition of polyploid cells are observed from $25 \mu \mathrm{M}$ concentration of etoposide onwards in a dose-dependent manner signifying the effect of etoposide on cell division. The result of drug treatment with time-dependent manner shows that the removal of drug also has the similar effect like dose-dependent manner. The attributes are significantly correlated $(p \leq 0.05)$ between themselves. All the result signifies the effectivity of the drug on plant system as an animal model. Higher concentration of etoposide has been found to reduce the callus growth. Such findings highlight the potentiality of the drug etoposide in the inhibition of cell division and growth in plant system. 


\section{Conclusion}

Present investigation evidently elucidates that etoposide, which is a potent anti-cancerous drug, having discernible anti-topoisomerase activity is also effective towards the inhibition of plant topoisomerase. The results establish a new possibility to screen out the anti-topoisomerase drugs using grass pea in vitro and in vivo system for preliminary screening of anti-cancerous lead molecule(s). Therefore, it may give an excellent opportunity to develop the anti-cancerous drugs using an easy and economical approach. This integrated approach would lead to save cost and time.

\section{Supplementary information}

Supplementary information accompanies this paper at https://doi.org/10. 1186/s42269-019-0217-4.

Additional file 1: Figure S1. Dendogram representing the cleavage core of topoisomerase II domains of plants (38 plant species) and human are well conserved.

Additional file 2: Figure S2. Comparison of etoposide-binding region of topoll cleavage core domain sequence of plants (38 plant species) and human.

\section{Abbreviations}

EDTA: Ethylenediaminetetra acetic acid; KIN: Kinetin; MS: Murashige and Skoog; NAA: a-Naphthalene acetic acid; PEG: Polyethylene glycol

\section{Acknowledgements}

The authors are thankful to the Department of Biotechnology, Haldia Institute of Technology, for providing necessary facilities to carry out the experiments of this work.

\section{Authors' contributions}

TRM and AS performed the experiments, analyzed the data, and wrote the manuscript. SD, AKD, and SD designed the work and corrected the manuscript. All authors read and approved the final manuscript.

\section{Funding}

Not applicable

\section{Availability of data and materials}

All data generated or analyzed during this study are included in this published article.

\section{Ethics approval and consent to participate}

Not applicable

\section{Consent for publication}

Not applicable

\section{Competing interests}

The authors declare that they have no competing interests.

\section{Author details}

'Department of Botany, Prabhat Kumar College, Purba Medinipur, Contai, West Bengal 721401, India. ${ }^{2}$ Department of Biotechnology, Haldia Institute of Technology, Purba Medinipur -, Haldia, West Bengal 721657, India. ${ }^{3}$ Department of Botany, Cytogenetics, Genetics and Plant Breeding Section, University of Kalyani, Kalyani, West Bengal 721235, India.
Received: 8 April 2019 Accepted: 22 October 2019

Published online: 03 December 2019

\section{References}

Adachi N, Miyaike M, Kato S, Kanamaru R, Koyama H, Kikuchi A (1997) Cellular distribution of mammalian DNA topoisomerase II is determined by its catalytically dispensable C-terminal domain. Nucleic Acids Res 25:3135-3142

Astashkina A, Mann B, Grainger DW (2012) A critical evaluation of in vitro cell culture models for high-throughput drug screening and toxicity. Pharmacol Ther 134:82-106

Baldwin EL, Osheroff N (2005) Etoposide, topoisomerase II and cancer. Curr Med Chem Anticancer Agents 5:363-372

Batra P, Sharma AK (2013) Anti-cancer potential of flavonoids: recent trends and future perspectives. 3. Biotech 3:439-459

Bax BD, Chan PF, Eggleston DS, Fosberry A, Gentry DR, Gorrec F, Giordano I, Hann MM, Hennessy A, Hibbs M, Huang J, Jones E, Jones J, Brown KK, Lewis CJ, May EW, Saunders MR, Singh O, Spitzfaden CE, Shen C, Shillings A, Theobald AJ, Wohlkonig A, Pearson ND, Gwynn MN (2010) Type II A topoisomerase inhibition by a new class of antibacterial agents. Nature 466 : 935-940

Carballo M, Gine R, Santos M, Puigdomenech P (1991) Characterization of topoisomerase I and II activities in nuclear extracts during callogenesis in immature embryos of Zea mays. Plant Mol Biol 16:59-70

Champoux JJ (2001) DNA topoisomerases: structure, function and mechanism. Annu Rev Biochem 70:369-413

Datta S, Basu D, Mukherjee KK (2008) PTC-1: a homologue of TFL1/CEN involved in the control of shoot architecture in Beta palonga. Curr Sci 94:89-96

Denayer T, Stohr T, Roy VM (2014) Animal models in translational medicine: validation and prediction. New Horiz Transl Med 2:5-11

Dong KC, Berger JM (2007) Structural basis for gate-DNA recognition and bending by type IIA topoisomerases. Nature 450:1201-1205

Elledge SJ (1996) Cell cycle checkpoints: preventing an identity crisis. Science 274:1664-1672

Felix CA (1998) Secondary leukemias induced by topoisomerase-targeted drugs. Biochim Biophys Acta 1400:233-255

Fortune JM, Osheroff N (2000) Topoisomerase II as a target for anticancer drugs: when enzymes stop being nice. Prog Nucleic Acid Res Mol Biol 64:221-253

Fukata H, Fukasawa H (1982) Isolation and partial characterization of two distinct DNA topoisomerases from cauliflower inflorescence. J Biochem 91:1337-1342

Fukata $H$, Fukasawa $H$ (1983) Further investigations on the characterization of DNA topoisomerases isolated from cauliflower inflorescence. Jpn J Genet 58: 425-432

Fukata H, Ohgami K, Fukasawa H (1986) Isolation and characterization of DNA topoisomerase II from cauliflower inflorescences. Plant Mol Biol 6:137-144

Hande KR (1998) Clinical applications of anticancer drugs targeted to topoisomerase II. Biochim Biophys Acta 1400:173-184

Hunt WF, Loomis RS (1976) Carbohydrate-limited growth kinetics of tobacco (Nicotiana rustica L.) callus. Plant Physiol 57:802-805

Issell BF, Rudolph AR, Louie AC (1984) Etoposide (VP -16-213): an overview. In: Issell BF, Muggia FM, Carter SK (eds) Current status and new developments. Academic Press, New York, pp 6-8

Jensen $\sqcup$ (2006) Co-evolution of transcriptional and post-translational cell-cycle regulation. Nature 443:594-607

Kaufmann SH (1998) Cell death induced by topoisomerase targeted drugs: more questions than answers. Biochim Biophys Acta 1400:195-211

Kaufmann SH, Gore SD, Miller CB, Jones RJ, Zwelling LA, Schneider E, Burke PJ, Karp JE (1998) Topoisomerase II and the response to ant leukemic therapy. Leuk Lymphoma 29:217-237

Laemmli UK (1970) Cleavage of structural proteins during the assembly of the head of bacteriophasge T4. Nature 227:680-685

Lam E, Chua NH (1987) Chloroplast DNA gyrase and in vitro regulation of transaiption by template topology and novobiocin. Plant Mol Biol 8:415-424

Laponogov I, Pan XS, Veselkov DA, McAuley KE, Fisher LM, Sanderson MR (2010) Structural basis of gate-DNA breakage and resealing by type ॥ topoisomerases. PLoS One. https://doi.org/10.1371/journal.pone.0011338

Loike JD, Horwttz SB (1976) Effect of VP-16-213 on the intracellular degradation of DNA in HeLa cells. Biochemistry 15:5443-5448

McClendon AK, Osheroff N (2007) DNA topoisomerase II genotoxicity and cancer. Mutat Res 623:83-97

Meyerowitz EM (2002) Plants compared to animals: the broadest comparative study of development. Science 295:1482-1485 
Mirski SE, Cole SP (1995) Cytoplasmic localization of a mutant M(r) 160000 topoisomerase lla is associated with the loss of putative bipartite nuclear localization signals in a drug-resistant human lung cancer cell line. Cancer Res 55:2129-2134

Murashige T, Skoog F (1962) A revised medium for rapid growth and bioassay with tobacco tissue culture. Physiol Plant 15:473-497

Nitiss JL (1994) Using yeast to study resistance to topoisomerase II-targeting drugs. Cancer Chemother Pharmacol 34:S6-S13

Nitiss $J$ (1998) Investigating the biological functions of DNA topoisomerases in eukaryotic cells. Biochim Biophys Acta 1400:63-81

Nitiss JL, Soans E, Rogojina A, Seth A, Mishina M (2012) Topoisomerase assays. Curr Protoc Pharmacol. https://doi.org/10.1002/0471141755.ph0303s57

Oakley BR, Kirsch DR, Morris NR (1980) A simplified ultrasensitive silver stain for detecting proteins in polyacrylamide gels. Anal Biochem 105:361-363

Pommier $Y$, Leo E, Zhang $H$, Marchand C (2010) DNA topoisomerases and their poisoning by anticancer and antibacterial drugs. Chem Biol 17:421-433

Pyke KA, Marrison J, Leech RM (1989) Evidence for a type II topoisomerase in wheat chloroplasts. FEBS Lett 242:305-308

Rowley JD (1998) The critical role of chromosome translocations in human leukemias. Ann Rev Genet 32:495-519

Rudenko GN (1992) Plant DNA-topoisomerase type II: isolation, characterization, and properties. Mol Biol 4:887-893

Samanta A, Datta S, Maity TR, Mandal A, Datta AK (2014) Assessment of methotrexate on dihydrofolate reductase activity, total RNA content and cell division of Lathyrus sativus L. Nucleus 57:129-134

Sclafani RA, Holzen TM (2007) Cell cycle regulation of DNA replication. Annu Rev Genet 41:237-280

Shirahige K (1998) Regulation of DNA-replication origins during cell-cycle progression. Nature 395:618-621

Thompson JD, Gibson TJ, Plewniak F, Jeanmougin F, Higgins DG (1997) The CLUSTAL_X windows interface: flexible strategies for multiple sequence alignment aided by quality analysis tools. Nucleic Acids Res 25:4876-4882

Wang JC (2002) Cellular roles of DNA topoisomerases: a molecular perspective. Nat Rev Mol Cell Biol 3:430-440

Wang XY, Ohtaka-Maruyama C, Pisano MM, Jaworski CJ, Chepelinsky AB (1995) Isolation and characterization of the 5'-flanking sequence of the human ocular lens MIP gene. Gene 167:321-325

Wang Y, Magnard JL, McCormick S, Yang M (2004) Progression through meiosis I and meiosis II in Arabidopsis anthers is regulated by an A-type cyclin predominately expressed in prophase I. Plant Physiol 136:4127-4135

Wilstermann AM, Osheroff N (2003) Stabilization of eukaryotic topoisomerase IIDNA cleavage complexes. Curr Top Med Chem 3:321-338

Wu CC, Li TK, Farh L, Lin LY, Lin TS, Yu YJ, Yen TJ, Chiang CW, Chan NL (2011) Structural basis of type II topoisomerase inhibition by the anticancer drug etoposide. Science 333:459-462

Xie S, Lam E (1994) Abundance of nuclear DNA topoisomerase II is correlated with proliferation in Arabidopsis thaliana. Nucleic Acids Res 22:5729-5736

Zang L, Pond SK, Gaut BS (2001) A survey of the molecular evolutionary dynamics of twenty-five multigene families from four grass taxa. J Mol Evol 52:144-156

\section{Publisher's Note}

Springer Nature remains neutral with regard to jurisdictional claims in published maps and institutional affiliations.

\section{Submit your manuscript to a SpringerOpen ${ }^{\circ}$ journal and benefit from:}

- Convenient online submission

- Rigorous peer review

- Open access: articles freely available online

- High visibility within the field

- Retaining the copyright to your article

Submit your next manuscript at $\boldsymbol{\nabla}$ springeropen.com 